\title{
Operational Capability Enhancement of NATO Rotary-Wing Forces ${ }^{1}$
}

\author{
Tamás BALI ${ }^{2}$
}

\begin{abstract}
Operational experiences of the recent past have revealed the significance of the helicopters and their combat and combat support capabilities in the asymmetric warfare environment. Recognizing the importance of the helicopters, the commanders of operations required an increasing number of rotary-wing assets onto the battlefield which has been traced back for various reasons by the participating nations. The situation becomes more complicated by the serious capability disparities among the rotary-wing forces already on the battlefield. The gaps in combat support lead consequently to the overall operational capability reduction in NATO forces. In my study, I look for solutions on how to increase the number of helicopters on the operational theatre, and how to enhance the operational capability of NATO rotary-wing forces.
\end{abstract}

Keywords: helicopter, operational capability, NATO, smart defence, training, interoperability

\section{Preface}

Operational experiences in Iraq and Afghanistan have revealed the significance of the helicopters and their combat and combat support capabilities in the asymmetric warfare environment. Recognizing the importance of the helicopters, the commanders of operations required an increasing number of rotary-wing assets onto the battlefield which has been traced back by budgetary and political reasons by the participating nations. This consequently led to the situation where helicopter deficiency became common at warzones. This problem was officially laid down even on NATO strategic level in 2009. ${ }^{3}$ [1]

In many cases, a nation cannot provide their helicopters due to their pilot training insufficiencies or simply there are not enough rotary-wing assets at their hand which can cover all home defence tasks and allied missions abroad. International deregulation also causes problems on required operational pilot qualifications and the way they must be reached. Pilot training procedures differ in each country. Moreover, some of the training elements can hardly be flown ${ }^{4}$ (or it is even impossible) at home bases due to the given countries' geographical possibilities.

The work was created in commission of the National University of Public Service under the priority project PACSDOP-2.1.2-CCHOP-15-2016-00001 entitled "Public Service Development Establishing Good Governance” in the Zoltan Bay Ludovika Workshop.

$2 \quad$ Ph.D., Colonel, Deputy Commander of HDF 86. Szolnok Helicopter Base; e-mail: bali.tamas@hm.gov.hu

3 The document entitled BI-SC Priority Shortfall Areas names 50 NATO essential operational capability shortages.

4 These can be: mountainous flight training, brown-out (desert) training or flight training over broad water surface. 
There are significant differences amongst the flying hours of a nation's helicopter pilots. In some countries, ${ }^{5}$ pilots get specific training focusing on special operations since it can answer best to the asymmetric challenges, while in others, there is no trace of a specialization. Here, helicopter pilot training covers the whole spectrum of training elements for each of the participating pilots. Obviously, the flying hours provided for them cannot be adequate for everything. Their pilot proficiency level will never reach the proficiency level of those, who concentrate on only one proficiency segment but on a professional level. Thus, significant proficiency differences can be observed amongst them on the operational theatre. This problem was highlighted by the document entitled Standardization of Qualification for NATO Helicopter Crews in Support of Land Operations of the NATO Joint Air Power Competence Centre (hereinafter: JAPCC). [2]

The different rotary winged aircraft (hereinafter: RW) platforms used by NATO nations do not help the situation. For those who use Western built helicopters, it is not a problem to meet the present operational challenges but with the Russian RW assets we can see the other side of the coin. Those military installations leg far behind the Western ones; along with this their upgrade to NATO standards proved to be a very expensive task. It is so expensive that many nations cannot even afford it for themselves. For example, in the case of Eastern helicopters, self-defence capability, secured voice and data communication, night and infra vision poses challenges. It is reasonable enough that during allied operations interoperability is hardly interpretable when the RW assets have different capabilities and the pilots have disparate proficiencies.

So, all in all, how can the operational capabilities of the NATO RW forces be improved? How can the number of the helicopters be increased on the operational theatre? Can it be a solution the utilization of the so called Smart Defence Concept, ${ }^{6}$ [3] which was announced at NATO’s Chicago Summit in 2012 to balance the defence expense's decreasement?

\section{NATO’s Smart Defence Concept}

There are few people in Europe who have not been affected by the economic crisis erupted in 2008. During the subsequent period, we had to face economic challenges, financial recession and an austerity policy at state level. This economic policy affected the defence sector as well, moreover, the budget constraints influenced it mostly. This could happen since there has not been any military action since the end of World War II in Europe, consequently it has become low priority to maintain strong military force for the nations. In order to bridge military capability gaps caused by the above-mentioned challenges, NATO's reaction was to utilize Smart Defence.

The program itself was firstly (officially) described in February 2010 by Anders Fogh Rasmussen NATO's former Secretary General, then it received an increasing role at the NATO Summits. This obviously does not mean that the idea had not been arisen beforehand, on the contrary, it received ever growing attention just after the outbreak of the economic crisis.

Apart from the United States, these are (as an example) Poland and the Czech Republic.

Due to the declining defence spending, NATO leaders adopted the so called "Smart Defence" concept in May

2012, Chicago, based on which the member states have agreed to share their military assets and operational

capabilities. 
Smart Defence is based on capability share, since to create and maintain all-embracing military capabilities for each of the individual nation's economy poses a huge burden. That kind of a concept has become evident for the allied nations in which they can share their own capabilities for cost-effectiveness. Upon the notion, each of the allied nation must seek its national strength in its defence sector, then their capability improvement must be concentrated toward these areas to be able to offer them to the Alliance later. The emerging capability gaps - in case of necessity - can be filled on cooperation with other countries. With this, NATO persuades the allied members for the international cooperation in order to help the Alliance itself with the nation's economic, industrial and political potential. [4]

However, some topic-related questions emerge:

1. Are the NATO allied nations willing to give up their weaker home defence capabilities and rely entirely on other nations?

2. What will happen in a case of an interest-conflict between two cooperating allied nations? Will they further provide their full capabilities to each other or serious resistance develops?

3. Is the nationalist way of politics still viable for some of the member states, or do they have to sacrifice a part of their national sovereignty by reducing some of their home defence capabilities?

This undoubtedly affects a NATO-sensitive area, namely the deepness of integration amongst the member nations (or-oppositely — do they incline to maintain their national autonomy?). Will the Alliance's interest overwhelm the member nation's? The answers for these questions defines the realism of the Smart Defence concept.

Even at a communication level the member states support the concept; still, it is worth briefly overviewing what they actually do for its realization. Concentrating on the rotary-wing arm, we can clearly see that the nations do not discard their already build operational and training capabilities.

- From an operational point of view, their home defence interests far outweigh Smart Defence's principles, even if their RW capabilities leg behind NATO interoperability minimum requirement standards. They know, that in the present asymmetric operational environment ${ }^{7}$ quick reaction and mobility has crucial importance.

- They know, that during any hostile activity, they will not have time to wait till international forces arrive. There will be an immediate need to deploy the land force.

- From a training point of view — on a conceptual level - there is no significant difference. The nations know, that an army can be abolished by the cancellation of pilot training. Moreover, the patriotic, motivated soldier (devoted to his or her country's defence), can only be socialized during a national training process.

Undoubtedly, pilot training can be bought from other allied member states, but in this case the flexibility disappears. In a case of urgent need, it can happen, that a given nation does not get proper number of training slots from its contracted counterpart. For these reasons, nations

\footnotetext{
Asymmetric operational environment should be considered when the opposing forces have different organizational structures, armament and way of warfighting. During an asymmetric conflict, actions do not need to be taken against a unified-, or not even against a single guerrilla force. While drafting a military counter action, it must be directed against dozens or even hundreds of different active groups. [5]
} 
are more likely to maintain their domestic helicopter pilot training systems, and offer their vacant training slots on flat cost to other countries (to keep it sustainable).

It is a perfect example for the above written thoughts, how the Czech and Croatian parties maintain their own rotary wing and training capabilities operational under the umbrella of the European Defence Agency (hereinafter: EDA) by the Czech led Multinational Helicopter Initiative's (hereinafter: MHI) HIP Helicopter Task Force program. [6] Multinational pre-deployment training for nations operating “Mi” helicopters in Afghanistan carried out in two phases and locations, funded by EDA. The Czech Republic provides the emergency procedural and operational training for RW aircrews at HTP Ostrava on their Mi-171 simulators. Croatia (Croatian Defence Forces) provides practical flying training with their own Mi-17sh helicopters. I must underline the fact again, that both countries receive significant financial reimbursement from the EDA. Such sum of money that covers expenses of the simulation centre in Ostrava, and the cost of running the Croatian helicopter fleet. Apart from these, the money covers not only the Hungarian aircrews' training, but the Czech's and Croats' as well.

But, if running the Smart Defence concept raises so many questions and if it works only on a principle level and actually seems unviable in practice, what can the solution be?

\section{Practical Solutions for Operational Capability Enhancement of Rotary-Wing Forces}

In the followings, I would like to outline the problems described above from a practical point of view. By writing this chapter, I intend to propose solutions to RW operational capability enhancement. To do that, I completed my research from several directions, on a global scale.

The capability itself obviously does not mean only having an adequate number of RW assets on the operational area. For an efficient task fulfilment, there must be equally trained (and also wisely thinking) aircrews, who are using the same tactics. The human resource is as important as the serviceability of the helicopters.

As for the first solution proposal, the cooperation improvement of NATO and EU forces, the synchronization of their flying tactics. At present, 25 out of the 28 NATO member nations are European. The principles of deployment of the European forces are laid down by the EDA, which in many cases are not synchronized with NATO regulations. On the part of NATO, the combat RW aviation arm's deployment principles are in the ATP-49(G) document. [7] The same purpose is served by the EDA HEP handbook of Standing Operating Procedures. [8] Obviously, this is not good, as it is. It cannot be allowed for any given EU associated aircrew to think differently in an operation led by NATO, and again in an operation led by the EU force. Effective deployment on a situation-based mindset change is unthinkable. But, which should be the preferred direction? Should it be the EU's or NATO's deployment principles to be put into the forefront? Is it possible to force a NATO dominant United States to accept EU developed flying tactics? As for my opinion, it is impossible, since the US military itself is stronger than the whole EU armed forces together.

On the other hand, the EU forces themselves presumably could not be able to counteract any of the Russian armed advance. In our present security-policy situation, for example the Baltic States would not be unconditionally happy with a pure EU force provided airspace defence over their region, since it could lead to a detriment of a well-functioning, security guarantee NATO cooperation. It is unacceptable for them (and even for the Polish as well) to 
face the Russians without the power of the US military. These nations do not inadvertently emphasize, that NATO is the strongest safeguard of the European defence.

So, since there is no formal cooperation between NATO and EDA, it must be (as a first step) established. Following this, using a constructive communication method, these two organizations must jointly develop and standardize their deployment principles.

To carry out common trainings and exercises. Considering the contemporary operational tempo, a nation concentrates on reaching the aircrews' combat ready training level ${ }^{8}$ as soon as possible. Internationalism can rarely be incorporated into this tight-paced training, so, there is a low possibility for any multinational joint training. However, as a result of some necessities, there are some training areas in which nations must rely on each other. These can be due to a geographical characteristic of a given country or because of the lack of local expertise or training asset. It is the same with our country, where pilots must complete their mountainous training in Slovenia and a Mi-17 emergency procedural training in the Czech Republic. Table 1 below shows the abroad training locations on a nation level.

Table 1. Cross-training locations of NATO member states. [9]

\begin{tabular}{|l|c|c|c|}
\cline { 2 - 4 } \multicolumn{1}{c|}{} & Mountainous training & Desert training & Extreme cold training \\
\hline The Netherlands & Italy & Spain & Norway \\
\hline Germany & Switzerland & Sardinia & \\
\hline Belgium & France & & Norway \\
\hline Denmark & Norway & & \\
\hline France & Germany & Djibouti & \\
\hline Poland & France & $\begin{array}{c}\text { Spain } \\
\text { Portugal }\end{array}$ & \\
\hline Slovenia & The Czech \\
Republic & & & \\
\hline
\end{tabular}

Ideally, trainings must be followed by such exercises in which pilots can improve their flying skills into routines.

There are serious difficulties in respect with the international exercises' execution. Each nation has its own flying procedures laid down in their regulations which are barely synchronized with each other.

Planning an international exercise takes a long time, [10] since the planners must consider all constraints, limitations and different regulations of the participating nations. Such

8 The helicopter pilot must be considered "Combat Ready", if he or she can carry out all of those flying and tactical manoeuvres which are on the one hand allowed by the given RW asset's design, and on the other hand are dictated by his or her unit’s regulations. 
limitations may apply to weapon use, flight manoeuvres and procedures, flyable weather conditions, pilot rest time, maximum flying hours per day and night under different visual an instrument conditions. Since the elaboration of a Standing Operating Procedures (hereinafter: SOP) based on broad-ranging national rules, the fulfilment of the NATO-wide multinational exercises become questionable. As a tendency, after the initial "flare-up", already in the planning period, member states are quitting the multinational exercises and are performing their own (national) exercises instead. It looks obvious, that until the synchronization of RW deployment principles of NATO and EU forces it is impossible to talk about internationalism. Likewise, there will not be any cooperation if the pilots' operational proficiencies differ in these two organizations. Moreover, it is not enough to sort out the dissimilarities separately; in the end, the organizations must unify. It is a very important task, since apart from the US military, there is no other country in the Alliance who could cover the entire spectrum of operational tasks with its manpower and weaponry. For NATO/EU nations there is no other choice than to match their segmented capabilities and "burnish" them together during international exercises. If this happens, the helicopter forces' interoperability-based operational capability will be greatly enhanced.

The question of RW aircrew's operational proficiencies' standardization is organically related to the previously written subject. More than four years ago NATO's JAPCC—analysing the capabilities of NATO forces-drawn up in its study entitled Enhancing NATO's Operational Helicopter Capabilities [9] that one of the biggest obstacle to an efficient operational deployment is a disharmony amongst coalition aircrews' proficiencies. The work started to solve this problem by NATO Standardization Agency's (hereinafter: NSA) Helicopter Inter Service Working Group (hereinafter: HISWG). The ultimate goal of the work is to develop a standardized, nation-wide accepted Allied Tactical Publication (hereinafter: ATP) document which clearly identifies the minimum qualification requirements of RW aircrews involved in allied operations. HISWG developed a draft study entitled ATP - 90 - Minimum Core Competence Levels and Proficiency of Skills for Helicopter Crew for NATO Operations upon the suggestions and guidelines of JAPCC's Standardization of Qualification for NATO Helicopter Crews in Support of Land Operations. [2] Overviewing the content of this study, it can clearly be expressed that adoption and application of the directives for all NATO/EU countries:

1. will improve the interoperability of all aircrews that undertake allied operations, thereby enhancing helicopter operations' effectiveness;

2. will provide the possibility for competent human resource management for all onscene commanders.

However, the situation outlined above can be tinged with two things. One is the different content of the pilot qualifications ${ }^{9}$ obtained, and the other is the density of flights required

9 Pilot qualification: A crewmember receives a qualification after passing an examination or completing an official course during which the individual demonstrates the knowledge, skill and aptitude required to safely and effectively complete the task within their approved national standards. For helicopter pilots, multiple qualifications can often be acquired within one specific course or training session. For example, during a specific mission qualification course, night vision goggles, low level flight, gunnery qualifications could be a part of the syllabus and could be acquired upon graduation of this course. 
to maintain pilot proficiencies. ${ }^{10}$ Probably the best way to clarify the differences on pilots' qualifications is to use an example for it. So, a pilot's qualification cannot be the same if an individual's mountainous training is performed at $1,000 \mathrm{~m}$ or at $4,000 \mathrm{~m}$. It is the same qualification on paper, but indeed, this is not so. There can be quite similar differences at formation-, instrument- or degraded visual environment flight qualifications. Likewise, missing an international standard, nations use their own regulation to maintain pilot proficiencies. Thus, a given proficiency can be maintained in one country with a 30 days-, and in another country with a 6 months' flight repetitions. It is again obvious, that it does not mean the same level of proficiency if the helicopter pilot repeats brown-out flight every 30 days or if he/she makes it every 180 days. Recognizing these anomalies, HISWG started the work on standardizing qualifications and proficiencies. Evidently, the extent of flight hours is limited by the economic opportunities of the individual nation which has a negative impact on the density of required flights to maintain proficiencies, yet a compromise solution must be found in this area as well.

Use of interlinked tactical simulators. Nations have individually created their own simulator capability due to financial aspects in order to facilitate their aircrews' flight technics and tactical training. The training itself can be carried out under the simulated active counter-activity of the enemy forces, under visual and instrumental meteorological conditions. Aircrews in the digital space-amongst others_-can perform support tasks for land forces, practice of their on-board weaponry and tactical manoeuvring. Naturally, this cost-effective training method is nowadays quickly spreading across the countries, but they have been created autonomously. Nations are exercising their own tactical procedures on them. Further emphasizing the facts previously written at common trainings and exercises, if these autonomous simulators were linked, it would open the possibility for international level exercises, which could enhance the RW forces' operational capabilities. I must underline to the margin of the exercise on network, the currently unsolved information protection problem which occurs when secured data and voice communication is transmitted via the Internet between the simulation centres.

Improvement of sharing operational lessons learnt and experiences. Today, only those nations can perform their RW tasks efficiently, who can quickly adopt themselves to the rapidly changing operational environment, who are able to evaluate the conflicts outcomes and lessons, who can transform their training to meet the newly arisen challenges and can implement those into their armed actions. It is easy for those nations, who are on the operational theatre and gaining and processing experiences on a daily basis. However, there are some others who are just planning to deploy their helicopter forces to the warzones. If they do not get information on the changes, they will not be capable to prepare for them either.

Not having proper information about the current challenges, these nations must face serious interoperability problems with the experienced ones that can only be eliminated by providing additional training for the aircrews on site. Since it cannot be the goal to train aircrews in a combat situation, competent operational lessons learnt and experiences shared must be created amongst the nations. If that happens, the whole helicopter branch could step ahead on the field of operational interoperability.

10 Pilot proficiency: A helicopter pilot is considered "proficient" when he or she, firstly, is deemed qualified per national guidelines, and secondly, is current and skilled. It is essential for commanders to know which specific mission assigned helicopter pilots are proficient in. 
Closely connected to the experience share topic, I have to underline the importance of the use of pilot exchange programs. These exchange programs are especially useful for those nations who have inadequate operational knowledge, since information transfer can be facilitated at the base of the host nation for a long-term period, from a representative of a more experienced nation. These programs are equally useful among the more experienced nations also, as they can even learn different tactical procedures and aircraft handling methods. The usefulness of these programs are shown by the widespread involvement of NATO nations. (Table 2)

Table 2. Pilot exchange programs at NATO member states. [9]

\begin{tabular}{|c|l|l|l|l|l|l|l|l|}
\cline { 2 - 9 } \multicolumn{1}{c|}{} & GBR & BEL & USA & CAN & FRA & DEN & NDL & POR \\
\hline NDL & & & & & & & & \\
\hline GBR & & & & & & & & \\
\hline USA & & & & & & & & \\
\hline CAN & & & & & & & & \\
\hline BEL & & & & & & & & \\
\hline DEN & & & & & & & & \\
\hline FRA & & & & & & & & \\
\hline SPA & & & & & & & & \\
\hline
\end{tabular}

We can see from Table 2, that the pilot exchange program works; however, its volume does not reach the level required for a sufficient flow of information and experience. For example, the Central and Easter-European countries ${ }^{11}$ tend not to participate in it. They are precisely those countries which upon the deficiencies and constrains of their air assets and operational experiences are lagging far behind their Western counterparts. In order to create an equal level of knowledge for an efficient operation, an existing pilot exchange program needs to be extended.

The implementation of a mandatory, standardized pre-deployment evaluation (TACEVAL). Despite the fact that RW forces have a decisive knowledge on the allied standards that apply to them, only a standardized evaluation system can ensure that they really have been implemented, or they are correctly applied. It is a special situation that the helicopters are not uniformly located in the armed forces. While in some countries helicopters serve at the Air Force, others are at the Land forces. The document entitled ACO Forces Standards Volume I-General [11] published by the Supreme Headquarters, Allied Powers of Europe (hereinafter: SHAPE) and Allied Command Operations (hereinafter: ACO) applies to all military branches and services, and must be applied at joint forces level.

SHAPE's ACO FS Volume III-Air Forces [12] specifically addresses the Air Force. Here, there is a detailed and exact regulation of the capabilities of the RW forces involved in Allied operations. The problem stems from the fact, that although ACO FS Volume I state

11 Hungary, the Czech Republic, Slovakia, Slovenia, Romania, Bulgaria, Poland. 
the joint forces level application requirement, it is only the Air Force's helicopter arm who utilizes it at its capability forming, the Army Aviation is not. This consequently leads to capability differences among these arms' RW forces. If the helicopter forces, regardless of their military affiliation, would have an equivalent understanding of ACO FS Volume III and they would also apply uniformly ACO Forces Standard Volume VI-SHAPE Tactical Evaluation Manual [13] (hereinafter: STEM) at the evaluation of their capabilities, the result would be the same high level of operational capability.

The implementation and interpretation of STEM should not be done individually by the nations, it must be applied to all NATO member states equally. If this happens, all those nations will also comply with the highest level of operational requirements who have not yet implemented the regulation written in NATO Standardization Agreements (hereinafter: STANAGs) and ATPs, as they will be forced to make extensive preparations to comply with the standards and they will be virtually levelled up.

Last, but not least, I have to emphasize the importance of the improvement of pilot English language proficiencies. The high English language proficiency is a key factor in the efficient mission completion. Without having communication, there is no interoperability, quick reaction capability slackens and decision-making cycle slows down.

\section{Conclusion}

The economic difficulties of the past period had a negative impact on the capabilities of the nations' armed forces. The helicopter branch was also not avoided by the negative effects of the constraints. The number of serviceable helicopters decreased, as well as the extent of the flying hours. In spite of these limitations - in what regards the security necessitiesthe level of operational ambition did not decrease. In addition to the fact that most NATO nations reduced the size of their armed forces, they refused to abandon their home-defence capability. This decision led to the declining tendency of national contributions to Allied operations. Obviously, this situation is untenable, since it weakens the overall capability of the Alliance which globally results serious security issues. It is unquestionable, that the level of operational capability of the NATO cannot be reduced, solutions need to be found to enhance it. In my present study, I dealt with the exploitation of the Smart Defence concept's opportunities and to outline practical procedures for securing rotary-wing capabilities in a sustainable manner. It is important to do this, as it is essential to ensure Air Force and Army aviation RW operational capabilities, as there is no country with a competent, powerful force, if it is unable to use it, to ensure operational tempo, to protect its forces, and to provide logistical support for it.

\section{References}

[1] NATO 2009 BI-Strategic Commands Priority Shortfall Areas. Brussels: NATO Allied Command Transformation, and Mons: Allied Command Operation, 2009.

[2] Standardization of Qualification for NATO Helicopter Crews in Support of Land Operations. Kalkar: NATO Joint Air Power Competence Centre, 2015. 
[3] Chicago Summit (May 2012) Declaration on Defence Capabilities: Toward NATO Forces 2020. www.nato.int/cps/en/natolive/official_texts_87594.htm (Downloaded: 15.03.2017)

[4] ETL A.: A NATO és az Okos védelem, az Okos védelem és Magyarország. biztonsagpolitika.hu (online) http://old.biztonsagpolitika.hu/?id=16\&aid=1379\&title=anato-es-a-smart-defence-a-smart-defence-es-magyarorszag (Downloaded: 19.03.2017)

[5] PORKOLÁB I.: Hibrid hadviselés: új hadviselési forma, vagy régi ismerős? Hadtudomány, XXV 3-4 (2015), 36-48.

[6] BALI T.: A helikopter erők felajánlásai, ezekből fakadó kihívások. Repüléstudományi Közlemények, XXIII, 3 (2013). http://repulestudomany.hu/folyoirat/2011_3/Bali_Tamas_2. pdf (Downloaded: 19.03.2017)

[7] ATP - 49(G) Edition G Version 1 Use of Helicopter in Land Operations. Brussels: NATO Standardization Office, 2015.

[8] EDA Helicopter Exercise Program Standing Operational Procedures. Brussels: EDA HEP, 2016.

[9] Enhancing NATO's Operational Helicopter Capabilities. Kalkar: NATO Joint Air Power Competence Centre, 2012.

[10] Gyakorlattervezői útmutató. Budapest: HM HVK Hadműveleti Főcsoportfőnökség Kiképzési Csoportfőnöksége, 2000.

[11] SHAPE ACO Forces Standards Volume I-General. Brussels: SHAPE, 2008.

[12] SHAPE ACO Forces Standards Volume III-Air Forces. Brussels: SHAPE, 2008.

[13] SHAPE ACO Forces Standard Volume VI.-SHAPE Tactical Evaluation Manual. Brussels: SHAPE, 2008.

[13] SHAPE ACO Forces Standard Volume VI.-SHAPE Tactical Evaluation Manual. Brussels: SHAPE, 2008.

[14] MAGYAR Z., RÉVAI T., PADÁNYI J.: The Usability and Significance of Tests Using Live Subjects for Measuring the Thermal Insulation Ability of Military Clothing. In. FÖLDI L., PADÁNYI J. (eds.): Effects of Climate Change on Security and Application of Military Force. Budapest: Nemzeti Közszolgálati Egyetem, 2014. 97-122. 